\title{
Recycling practices of crushed MgO-C bricks and dolomite sinter fines used as a slag conditioning additive in the EAF
}

\author{
T. C. Avelar ${ }^{1}$, A. F. Veiga ${ }^{1}$, E. Gueguen ${ }^{2}$ \& J. R. Oliveira ${ }^{3}$ \\ ${ }^{I}$ Technical Marketing Department, Magnesita Refractories GmbH, \\ Germany \\ ${ }^{2} R \& D$ Department, Magnesita Refractories GmbH, Germany \\ ${ }^{3}$ Metalurgic and Materials Department, \\ Instituto Federal do Espirito Santo (IFES), Brazil
}

\begin{abstract}
Reduction of production cost on electric arc furnace (EAF) technology is strongly dependent on the efficiency of electrical energy introduced into the metal bath. Beyond EAF technology, the slag foaming process is currently applied to some other equipment for steel production aiming to save energy, productivity improvements, enhance the refractory service life and inhibit steel re-oxidation and can be achieved by improving the thermal efficiency heat transfer to the scarp by stabilizing of the arc activity through foamy slag practice. All these effects can be achieved by guaranteeing the optimum amount of $\mathrm{MgO}$ in the slag to achieve the best foaming quality. The recycling options of Crushed $\mathrm{MgO}-\mathrm{C}$ spent refractories removed from EAF without complex and costly beneficiation have been evaluated with emphasis on the application as a slag conditioner because of their high $\mathrm{MgO}$ content. A specially prepared briquettes content crushed $\mathrm{MgO}-\mathrm{C}$ spent refractories and Dolomite Sinter obtained from rotary kilns process were used as a slag conditioning agent on the slag and metal phase boundary aiming an optimum amount of $\mathrm{MgO}$ in the slag and the formation of gas bubbles needed to achieve the best foaming quality necessary for the foaming effect. After several tests in the laboratory simulating EAF conditions a final formulation was defined. Together with a computer model based on published phase-diagrams which graphically maps the chemistries for the dual saturated slag, the optimum $\mathrm{MgO}$ amount to control the slag composition while the equipment is being operated was defined. The additional
\end{abstract}


amount of briquettes for achieving the optimal foaming conditions was then defined. Considering the data presented in the scientific literature and the laboratory results, this type of approach could help the melt shop extend refractory service life, increase the energy efficiency, increase productivity, and decrease the amount of slag.

Keywords: electric arc furnace (EAF), foaming slags, refractory recycling slag conditioning.

\section{Introduction}

The worldwide increase of the steel consumption rate seen in the last few years has impacted directly in steel production [1]. This increase has led the steel sector to search and develop a new production pattern with higher efficiency with lower costs.

Within this scenario, the processes of electric arc furnaces (EAF) steel shops have suffered a variety of modifications in order to cope with the current market demands. According to Nakahara [2], among these changes, the increase in the useful life of the refractory materials, reduction of material costs and the increase of the operational safety of the production processes can be found.

The refractory consumption is directly related to the steel production. However, this relationship between the steel production and the specific refractory consumption $(\mathrm{kg} / \mathrm{ton}$ steel) has been reduced by the use of new methodologies that permit an increase in the useful life of the refractory materials used in the production processes. In the last 30 years the consumption of refractory/steel production rate has been reduced from 20 to $10 \mathrm{~kg} / \mathrm{ton}$ [3].

The EAF companies have a huge interest at recycling their spent refractories, since some of them are located in developing urban areas and do not have available space to landfill the spent material or the costs to dispose it are too high. This is also the case for the refractory industry, as the manufacturing process generates remaining material that needs to be disposed. In both cases, the companies see this practice as part of its residual management, gaining a competitive advantage of business $[4,5]$.

The process of recycling spent refractories has been carried out for a long time in many steel plants, as the case of the MgO-C bricks from EAFs. This practice may be simple, however, has been developed, in general, on empirical grounds. Most of the applications of spent refractory material are limited due to quality, availability, consistency, and the transportation cost [4]. One of the applications which have shown good results is to reuse spent refractories as an EAF foamy slag additive to decrease the amount of fluxes and improve the foaming conditions [6-9].

The slag foaming process is currently applied to some equipment for steel production (i.e., electric arc furnace (EAF), basic oxygen furnace (BOF), etc.) aiming to save energy, productivity improvements, enhance the refractory service life and inhibit steel re-oxidation. In the case of EAF, the foamy slags shield the electrical arcs, preventing radiation energy loss, eliminating arc flares, saving overall energy and extending refractory service life. Some studies showed 
$[10,11]$ that the foaming slag methodology can reduce $10-30 \%$ of the electrical consumption and $25-63 \%$ of the refractory consumption. Figure 1 presents a scheme of the effect of the foaming slag on the efficiency of the power input for different levels of coverage of the arc created by the electrode.

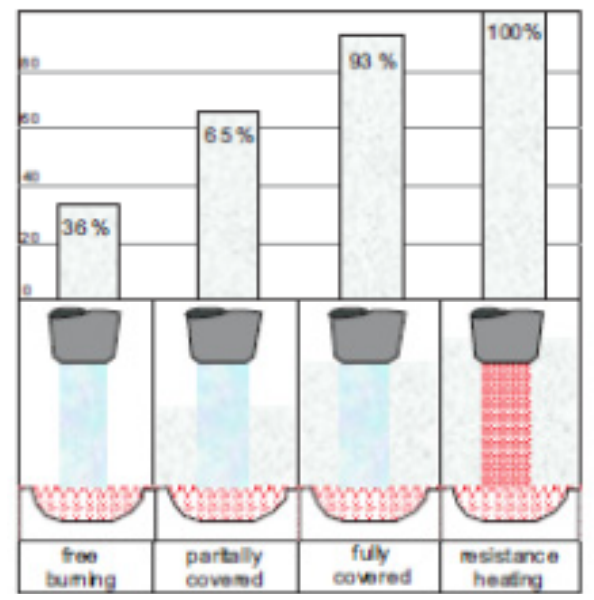

Figure 1: Influence of foaming slag to the efficiency of power input [12].

There are basically two requirements for foaming: (1) reactions or processes that generate small gas bubbles and, (2) suitable slag properties to keep the bubbles as stable foam $[11,13]$.

The foaming of the slag is done by the direct injection of oxygen and carbon into the electric furnace baths (Figure 2). After that, the carbon reacts with $\mathrm{FeO}$ from the slag, generating $\mathrm{CO}(\mathrm{g})$, which is mainly responsible for the foaming effect (Eq. (1)) [10] generating gas bubbles that enables the $\mathrm{FeO}$ generation in the liquid (Eq. (1)).

$$
\begin{gathered}
\mathrm{Fe}_{(1)}+1 / 2 \mathrm{O}_{2(g)} \rightarrow \mathrm{FeO}_{(1)} \\
\mathrm{FeO}_{(s, l)}+\mathrm{C}_{(s, l)} \rightarrow \mathrm{Fe}_{(l)}+\mathrm{CO}_{(g)}
\end{gathered}
$$

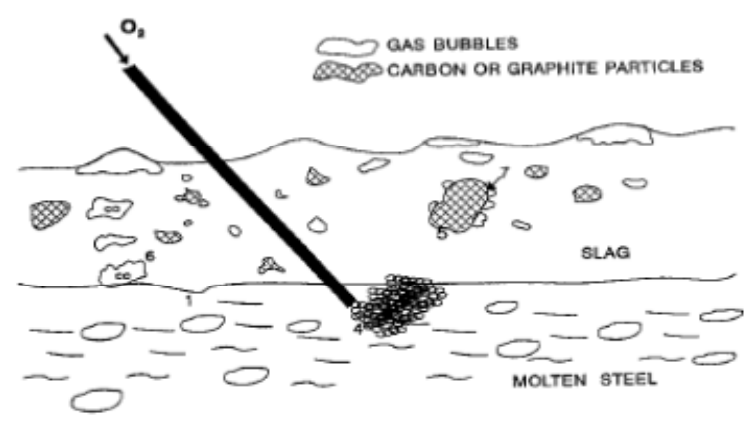

Figure 2: Sketch of the transformations taking place in EAF equipment during the slag foaming procedure [15]. 
The foaming slag has been deeply investigated in EAFs and basic oxygen furnaces [16-21]. However, the correct control and optimization of the foam generation on the slag surface are still limited and some factors such as basicity, $\mathrm{FeO}$ concentration, surface tension, viscosity and how the suspended second phase particles in the liquid act directly in the slag foaming behavior, need some further understanding.

Among the responsible factors for the formation and maintenance of the foaming slag during the steel production are the chemical composition of the slag, the process temperature, the injection and generation of gases, and also, the physical characteristics of the slag, like its viscosity and superficial tension. To reach an "optimum foaming slag" all these factors must be appropriately controlled or, in some cases, induced.

In this context, the objective of the present study is to propose an improvement to the foaming slag process through the addition of a mixture of recycled refractory materials of MgO-C (commonly used in EAF) and dolomite sinter fines $(\mathrm{CaO} . \mathrm{MgO})$ during the process of metal fusion in the EAF, intending to reach the optimum saturation point of $\mathrm{MgO}$ in the slag, inducing the formation and maintenance of a beneficial foaming slag to the process.

\section{Experimental method}

\subsection{Materials characterization}

Pretorius and Carlisle [22] has reported the important relationship between the $\mathrm{MgO}$ saturated slags to slag foaming and refractory wear. This source of $\mathrm{MgO}$ in the slag can be either by pure dolomite additions to the slag, waste $\mathrm{MgO}-\mathrm{C}$ refractories addition to the slag, or from the working face of the refractory lining dissolving into the slag. In this context, two source of $\mathrm{MgO}$ available to the refractory industry were selected:

1) $\mathrm{MgO}-\mathrm{C}$ spent refractory;

2) Dolomite sinter or Dead-burned dolomite fines.

$\mathrm{MgO}-\mathrm{C}$ spent refractories were obtained from several EAF linings, which usually use this type of material due to the high melting point of $\mathrm{MgO}$ and the slag compatibility. Carbon is added to the refractories to enhance their nonwetting properties. For specific regions with high oxygen content, some antioxidants such as aluminium (Al) and silicon ( $\mathrm{Si}$ ) are also added to the refractories to prevent carbon oxidation.

Table 1 shows the chemical composition of new and spent $\mathrm{MgO}+\mathrm{C}$ refractories from an EAF. The chemistry indicates that this spent refractory is fairly clean.

Table 1: $\quad$ Characterization of the new and spent $\mathrm{MgO}+\mathrm{C}$ refractory.

\begin{tabular}{cccccccc}
\hline & $\% \mathrm{MgO}$ & $\% \mathrm{CaO}$ & $\% \mathrm{SiO}_{2}$ & $\% \mathrm{Al}_{2} \mathrm{O}_{3}$ & $\% \mathrm{FeO}$ & $\% \mathrm{MnO}$ & $\% \mathrm{C}$ \\
\hline New & 91,41 & 1,65 & 2,19 & 3,79 & 0,81 & 0,06 & 10,65 \\
Spent & 88,24 & 2 & 1,72 & 1,71 & 1,75 & 3,42 & 9,74 \\
\hline
\end{tabular}


The $\mathrm{MgO}+\mathrm{C}$ spent refractories bricks have been analyzed by X-ray scattering technique. The X-ray analysis indicated the presence of carbon in the form of graphite $(\mathrm{C})$, the presence of periclase $(\mathrm{MgO})$, forsterite $\left(\mathrm{Mg}_{2} \mathrm{SiO}_{4}\right)$ and spinel $\left(\mathrm{MgAl}_{2} \mathrm{O}_{4}\right)$. The formation of the spinel phase was due to reaction of the $\mathrm{Al}$ metallic present in the bricks (used as antioxidant) with the magnesium from the periclase. The forsterite phase was formed by the reaction of $\mathrm{MgO}$ from the refractory with process slag consists basically by $\mathrm{SiO}_{2}-\mathrm{CaO}-\mathrm{MgO}-\mathrm{Al}_{2} \mathrm{O}_{3}$. Furthermore, it has been observed the presence of a fourth phase, brucite $\left(\mathrm{Mg}(\mathrm{OH})_{2}\right)$, indicating the beginning of the hydration process of the material after the demolition of brick.

The Dolomite sinter or Dead-burned dolomite is generally used in the refractory industry for the refractory made by firing dolomite, with or without additives, at high temperature to produce dense, well-shrunk particles. This refractory is widely used wherever steel is refined using basic slag and can stand temperatures up to $2.300^{\circ} \mathrm{C}$. It is used for original hearth installations in the electric arc furnaces as well as for hearth maintenance. Dolomite refractories are also used in steel ladles and in cement industry during clinker manufacture.

Dead burnt refractory dolomite is produced in rotary kilns. Generally highgrade dolomite, containing combined impurities less than $3 \%$, is selected for dead-burning. As it is difficult to densify high purity dolomite in a rotary kiln, it is customary to use some mineralizes, as iron oxide, to facilitate the process. The manufacturing process varies with the grade of the desired Dead-burnt refractory dolomite.

After the Dead burned dolomite leaves the kiln, it is screened to remove the fines and undersized particles $(<8,0 \mathrm{~mm})$ generated. This fine fraction is normally exposed to lower temperatures than the larger fraction, which results in material with moderate to low chemical reactivity (not fully calcined). Due to these characteristics, this material cannot be used for the manufacture of refractory brick, creating disposal issues. In some locations in the Europe, companies may pay high fees to landfill these fines.

Table 2 shows the chemical composition of the Dead-burned dolomite (DBD) fines from a rotary kiln process. The chemistry indicates that this material can also be applied as $\mathrm{MgO}$ source.

Table 2: $\quad$ Characterization of the dead-burned dolomite (DBD) fines.

\begin{tabular}{cccccccc}
\hline & $\% \mathrm{MgO}$ & $\% \mathrm{CaO}$ & $\% \mathrm{SiO}_{2}$ & $\% \mathrm{Al}_{2} \mathrm{O}_{3}$ & $\% \mathrm{FeO}$ & $\% \mathrm{C}$ & $\% \mathrm{LOI}$ \\
\hline $\begin{array}{l}\text { DBD } \\
\text { Fines }\end{array}$ & 42,00 & 54,50 & 1,04 & 0,62 & 0,69 & 0,51 & 1,80 \\
\hline
\end{tabular}

\subsection{Foaming experiment}

The laboratory experiment was defined in order to establish an adequate chemical composition of the briquettes for effective foaming of carbon steel slags. The material contained $\mathrm{MgO}-\mathrm{C}$ spent refractory, Dead-burned dolomite fines, carbon carriers, iron oxide scales and natural binder such as a vegetable paste (low water content). The briquettes were made by compression of the 
mixture by means of a press device. Several formulations were defined based on theoretical considerations and economical aspects. The briquettes were prepared in dimension of 1 inch $(2,54 \mathrm{~mm})$. The experimental phase was carried out by making several trials varying the process temperature. Samples of metal and slag phases for chemical analysis in order to optimize the foam ability were taken.

The first stage of the experiment was performed in a laboratory induction furnace powered by a transformer, $50 \mathrm{kVA}$ rated power, supplied by a voltage of $480 \mathrm{~V}$ to simulate an EAF real condition and investigate the influence of the briquettes on the height and stability of the generated foams. Figure 3 illustrates experimental induction furnace used to develop the trials and the apparatus used to measure the slag height when a briquette is added into the molten slag the test.

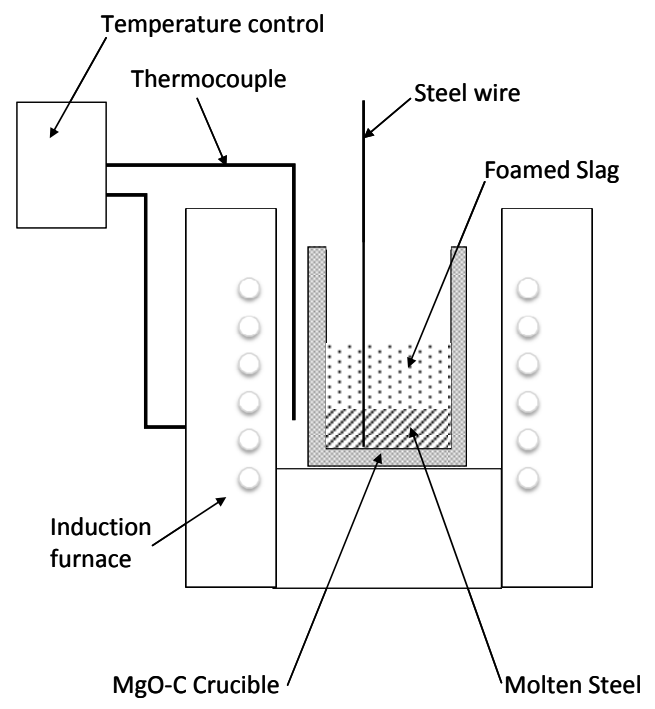

Figure 3: Sketch of the experimental induction furnace and the apparatus to measure the slag foaming height.

For the tests, an MgO-C crucible, was charged with steel ingots $(229 \times 70 \times 30$ $\mathrm{mm} \pm 1 \mathrm{~mm}$ ) of predefined chemical composition (SAE 1020), in order to simulate an EAF real condition. The furnace was heated until the total charge was molten. After the scrap melting, a mixture of an industrial slag of defined composition and weight (about $200 \mathrm{~kg}$ ) was added and melted accompanied by samplings for metal and slag chemistry. In Table 3, the range of mother slag composition is shown.

Table 3: Chemical composition of the synthetic slag used in the experiment.

\begin{tabular}{ccccccc}
\hline$\% \mathrm{CaO}$ & $\% \mathrm{SiO}_{2}$ & $\% \mathrm{Al}_{2} \mathrm{O}_{3}$ & $\% \mathrm{FeO}$ & $\% \mathrm{MnO}$ & $\% \mathrm{MgO}$ & $\% \mathrm{P}_{2} \mathrm{O}_{5}$ \\
\hline 52,05 & 21,77 & 4,04 & 38,83 & 5,71 & 7,89 & 0,01 \\
\hline
\end{tabular}


The temperature was controlled close to $1.700^{\circ} \mathrm{C}$, the initial height of the slag recorded and the foaming briquettes added into the furnace. Since the foaming initiation until the cease of the foam, the slag height and the foaming duration were measured. The experiments were carried out with a total duration time of 30 minutes. When the foaming process was ceased, sampling of the slag was done again and the metal with slag was tapped into a mould.

The slag height was measured by the slag adhesion length on a steel rod inserted in the crucible (as shown in Figure 3). The range of the foam height was calculated by the subtraction of the initial slag height before briquettes addition to the highest measured value.

The trials were performed for six different foaming mixtures with different amount of spent $\mathrm{MgO}-\mathrm{C}$ refractories and Dead-burned Sinter dolomite fines. Additional amounts of hematite (Fe2O3) were added to the mixture to assure a briquette density between the slag and the steel $\left(2-3 \mathrm{~g} / \mathrm{cm}^{3}\right)$. In all formulations carbon carriers (pet coke) were added.

\section{Experimental results}

The experimental results of the slag foamability translated into slag height for the six different formulations are shown in Figure 4.

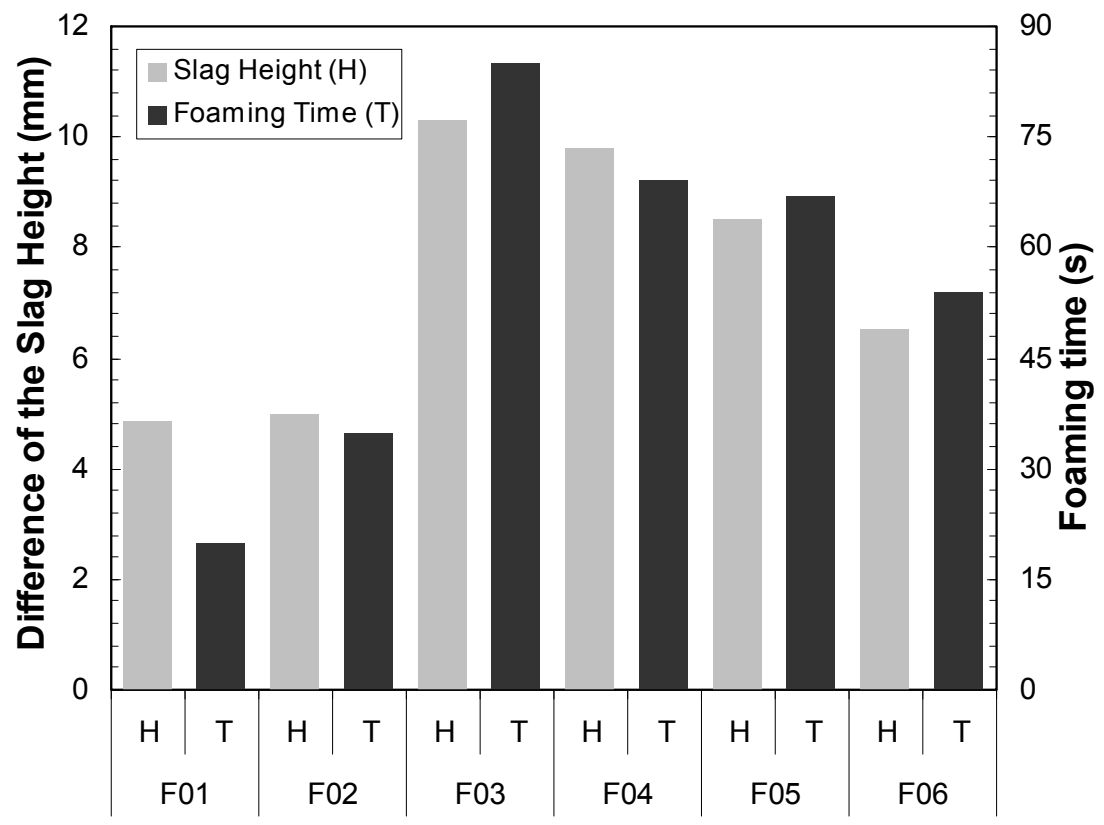

Figure 4: Differences of slag heights for the different formulations of foaming material during. 
The foaming behavior was different in each experimental condition. The results indicate that the highest foamability was with the formulation F03, while the lowest one was observed with formulation F01. In some cases, slag foaming began to take place just after the first addition of briquette but in other cases, slag foaming gradually occurred after the end of briquette addition.

According to these results, the following three parameters were introduced to explain the slag foaming behavior results:

1) Slag Basicity B3;

2) Decrease of $\mathrm{FeO}$ in the Slag;

3) $\mathrm{MgO}$ Saturation in final the Slag.

\section{Discussion}

\subsection{Influence of the slag basicity (B3)}

Figure 5 shows the relation between the maximum slag height and the slag basicity, with the same condition of temperature and initial slag composition for each formulation.

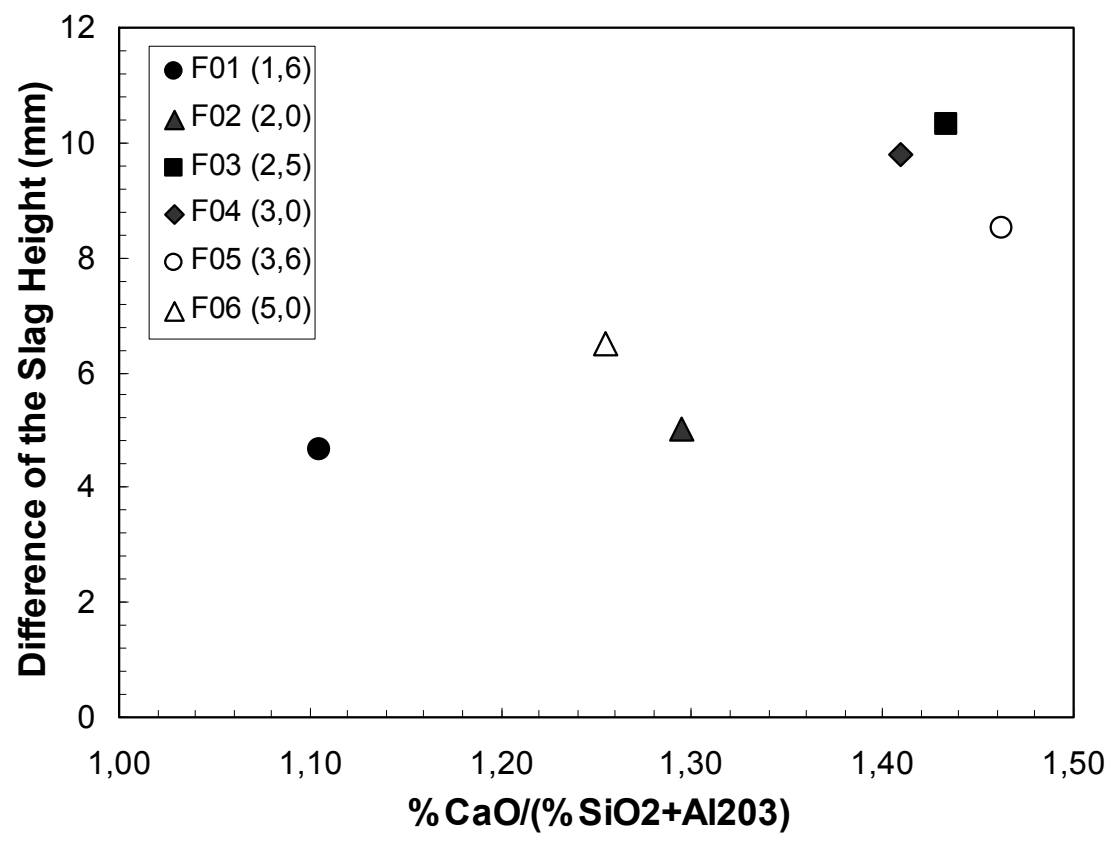

Figure 5: Relationship between the maximum slag height and final slag basicity (B3) for each formulation and the relationship between the two main raw materials. 
The amount of MgO-C Spend Refractory/Dead Burned Dolomite in each formulation was also taken into account. The maximum foaming height was found when the relationship between the two raw materials was around 2,5 (F03). This can be explained due to an increase of the $\mathrm{CaO}$ content in slag because of the higher amount of Dead Burned Dolomite, which has a higher $\mathrm{CaO}$ content. By increasing $\mathrm{CaO}$ content in the slag the surface tension will increase and viscosity will decrease. This is because solid particles such as $2 \mathrm{CaO}-\mathrm{SiO} 2$ precipitate at higher $\mathrm{CaO}$ contents, and the particles significantly increase foam stability. Therefore, the precipitation of second-phase particles has a larger effect than the increase in surface tension and decrease in viscosity on foam stability for these slags

\subsection{Influence of $\mathrm{FeO}$ decreasing in the slag}

Figure 6 shows the relationship in the slag and the maximum slag height and the amount of $\mathrm{FeO}$ contained in the final slag. It can be seen that the lowest $\mathrm{FeO}$ is achieved by the formulation F03, which has also the best foaming results, time and maximum height. As already presented, the reduction of $\mathrm{FeO}$ in the slag is done by reaction with the carbon content present in the briquette from the pet coke and in the $\mathrm{MgO}-\mathrm{C}$ spend. This reaction will generate $\mathrm{CO}$ gas bubbles $\mathrm{CO}$, increase the slag foaming height. Therefore, the maximum slag height increased with the decrease of the $\mathrm{FeO}$ content in the slag. This can be translated as the maximum $\mathrm{CO}$ gas generation.

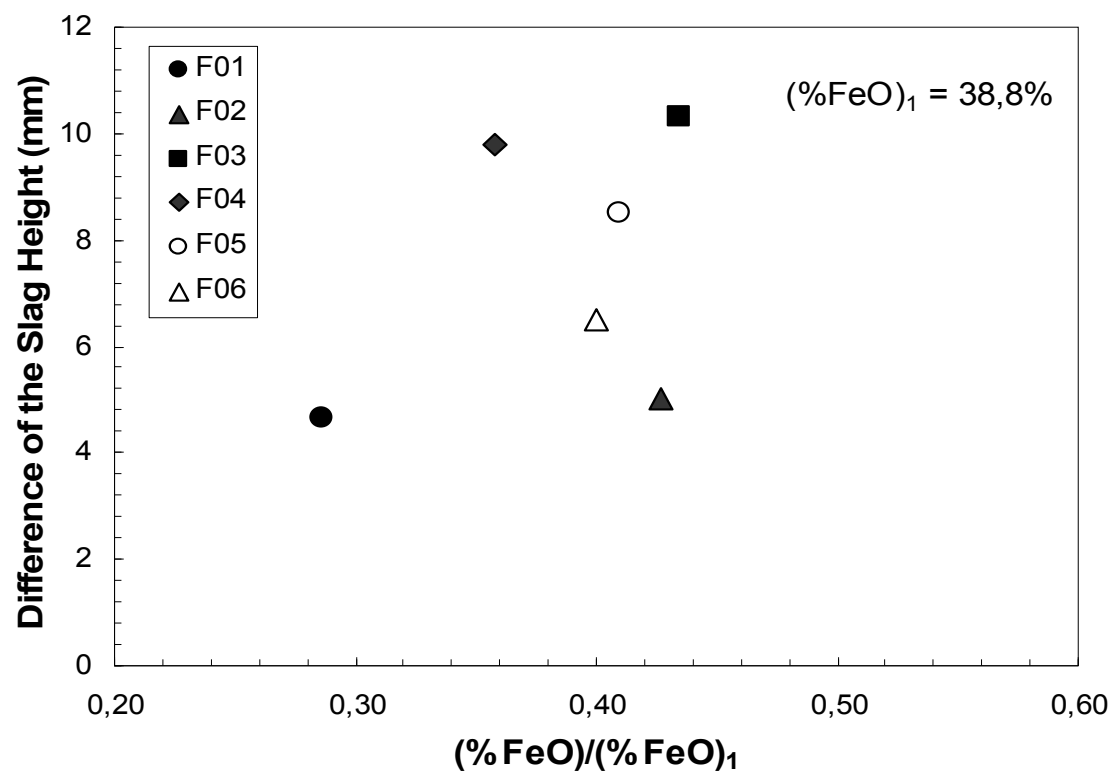

Figure 6: Relationship between the maximum slag height and the change in $(\% \mathrm{FeO}) /(\%, \mathrm{FeO})_{1}$ in the slag for each formulation. 
Another point is that $\mathrm{FeO}$ has strongly influences the effective viscosity and hence the foaming properties of the slag. An increase in the $\mathrm{FeO}$ content will increase the fluidity of the slag, resulting in a decrease in the foaming height.

\subsection{Influence on the MgO saturation limit in the slag}

As previously mentioned, the "optimum" slag at EAF operating temperature is a molten $\mathrm{MgO}$ saturated slag with the presence of suspended second phase particles.

Pretorius and Carlisle [22] developed new maps to represent the saturation limits of $\mathrm{MgO}$ for $\mathrm{CaO}-\mathrm{SiO} 2-\mathrm{FeO}-\mathrm{MgO}-\mathrm{Al} 2 \mathrm{O} 3$ slags, as a function of $\mathrm{MgO}$ and $\mathrm{FeO}$ content at a constant basicity (B3) and temperature, called Isothermal Saturation Diagrams (ISD). Figure 7 shows the $\mathrm{MgO}$ saturation boundaries as a function of $\mathrm{FeO}$ content for ternary basicities from 0-1,5 range with the final slag results for each formulation. In this diagram $\mathrm{C} 2 \mathrm{~S}$ corresponds to calcium disilicate and MW to magnesium wüstite. The shaded region represents the ideal region recommended to saturate the slag in $\mathrm{MgO}$ with small concentration of undissolved particles to increase the viscosity of slags. Below the saturation line the slags present low viscosities.

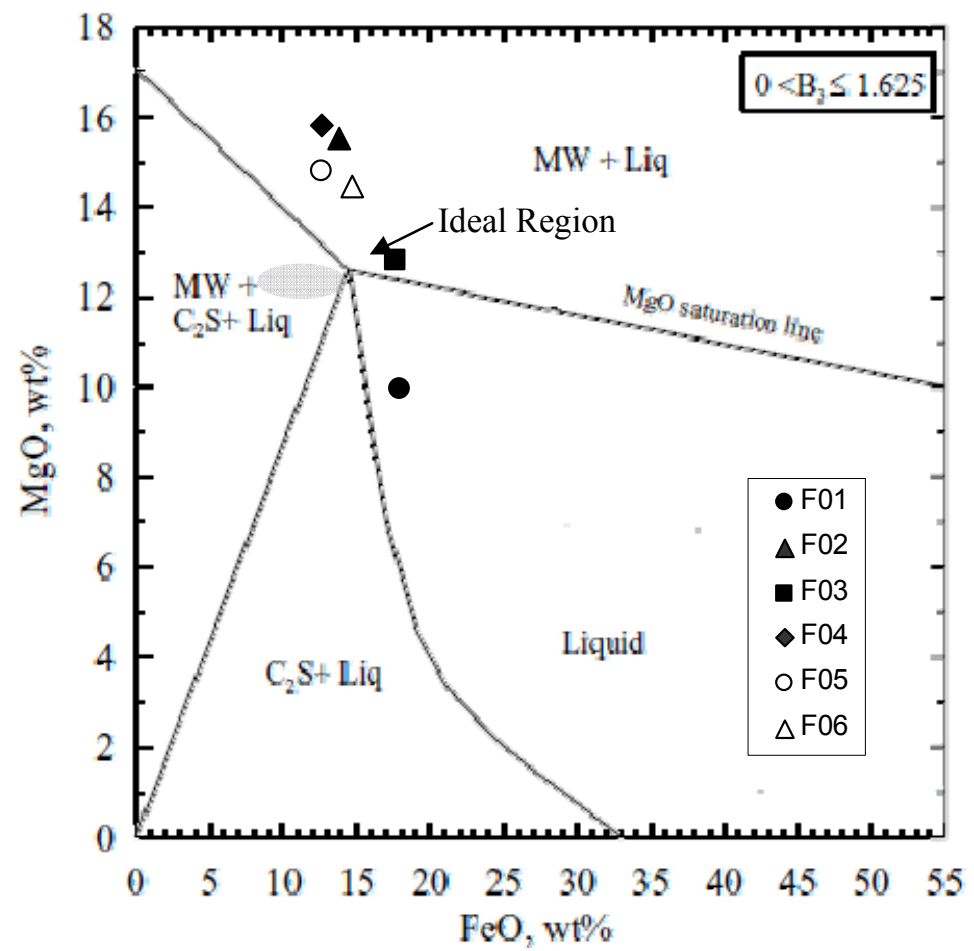

Figure 7: Relationship between the maximum slag height and the change in $(\% \mathrm{FeO}) /(\%, \mathrm{FeO})_{1}$ in the slag for each formulation. 
The Isothermal Saturation Diagrams (ISD) shows that the formulation which is close to ideal foamy slag chemistry region is formulation F03. Therefore, this formulation was selected to carry out the evaluation of usage of recycling materials on a large scale industrial trial.

\section{Conclusions}

The usage of recycled spent MgO-C Refractories and Dead burned dolomite fines as slag conditioners to saturate slags with $\mathrm{MgO}$ has a positive impact on slag foaming behavior. Several formulation containing different amount of the two recycled material were investigated through a foaming experiment in laboratory simulating an EAF operation conditions. According to this investigation, a formulation having ratio of 5:2 of the recycling materials has shown the best results in terms of slag height and the effect on $\mathrm{MgO}$ saturation limits. The slag foaming experimental results indicate that utilization of recycling material as a slag conditioners could play an important role in slag foaming and therefore to be used to control the foaming behaviour in an EAF operation.

\section{References}

[1] INSTITUTO AÇO BRASIL. Base de dados. Available at: $<$ http://www.acobrasil.org.br/site/portugues/numeros/estatisticas.asp > Accessed: 25th March, 2011.

[2] NAKAHARA, Tsuneo, Innovation in a Borderless World Economy. Research and Technology Management, v. 40, n. 3, p.7-9, May/June, 1997. Editora Arte e Ciência.

[3] LOBATO, E., Cadeia de Refratários Relatório Técnico 71. Ministério de Minas e Energia -Secretaria de Geologia, Mineração e Transformação Mineral- SGM. Banco Internacional para a Reconstrução e Desenvolvimento - BIRD. Brazil, August, 2009. Available at: $<$ http://www.mme.gov.br/>

[4] BENNET, James P., et al. An overview of DOE's program to recycle/reuse spent refractories as a slag conditioner and to extend refractory service life in the EAF. AISE Conference. USA, October, 2000.

[5] SEMLER, C. E., Refractories Review: Recycling Refractories. Symposium Proceedings. December, 2000.

[6] BENNET, James P., et al. Spent Refractory as Slag Conditioning Additive in the EAF.58th Electric Furnace Conference and 17th Process Technology Conference. Electric Arc Furnace Proceedings, v.58, p. 379-390, USA, November, 2000.

[7] GONZALEZ, R. G. L., et al. Recycling MgO-C refractory in the EAF of Mittal Steel Lázaro Cárdenas. Iron and Steel Technology, p. 76-84, USA, February, 2006. 
[8] BENNET, James P., et al. An overview of DOE's program to recycle/reuse spent refractories as a slag conditioner and to extend refractory service life in the EAF. AISE Conference. USA, October, 2000.

[9] LULE, R. et al. Recycling MgO-C Refractory in the EAF of IMEXSA. AISTech 2005 Proceedings, p. 605-615. Charlotte North Carolina, EUA, Maio 9-13, 2005.

[10] KWONG, K. S.; BENNET, J. P. Recycling practices of spent MgO-C refractories. Journal of Minerals and Materials Characterization and Engineering, v.1, n. 2, p. 69-78, 2002.

[11] KWONG, Kyei-Sing.; BENNET, James P.; KRABBE, Rick; PETTY, Art; THOMAS, Hugh. Thermodynamic calculations predicting $\mathrm{MgO}$ saturated for use in EAF steel production. In Proceedings of TMS 2009 - 138th Annual Meeting and Exhibition, p. 63-70, USA, February, 2009.

[12] SEDIVY, C. H.; KRUMP, R., Tools for foaming slag operation at EAF steelmaking. Metallurgy and Materials, v. 53, n. 2, p. 409-413, 2008.

[13] ANDRADE, Maria L. A.; CUNHA, Luiz M. da Silva; SOUZA, E.S. S.. Minério de Ferro - mercado em ascensão. Mineração e Siderurgia, n. 6. Gerência Operacional 3/Banco Nacional do Desenvolvimento, Rio de Janeiro. Brazil, January, 2003.

[14] KIM, H. S.; MIN, D. J.; PARK, J. H., Foaming Behavior of $\mathrm{CaO}-\mathrm{SiO}_{2}-$ FeO-MgOsatd-X $\left(\mathrm{X}=\mathrm{Al}_{2} \mathrm{O}_{3}, \mathrm{MnO}, \mathrm{P}_{2} \mathrm{O}_{5}\right.$, and $\left.\mathrm{CaF}_{2}\right)$ Slags at High Temperatures. ISIJ International, v. 41, n. 4, p. 317-324, 2001.

[15] SEGADÃES, Ana M.. Refratários. Universidade de Aveiro, Portugal, 1997.

[16] MORALES, R. D., et al. The slag foaming practice in EAF and its influence on the steelmaking shop productivity. ISIJ International, v. 35, n. 9, p. 54-62, 1995.

[17] OLTMANN, H.; GURLEY, T.; TRAPP, M..The safe use of high power in a DC arc furnace. 59th Electric Furnace Conference, 2001.

[18] JIANG, R., FRUEHAN, R. J., Slag foaming in bath smelting. Metallurgical and Materials Transactions B, v. 22, p. 481-489, 1991.

[19] KITAMURA, S., OKOHIRA, K., Influence of slag composition and temperature on slag foaming. ISIJ international, v. 32, n. 6, p.741-746, 1992.

[20] NOVÁK, M., STRAKA, J., PRIBYL, M., Influence of the slag foaming process applied in high alloyed steel production on refractory wear of EAF at Pilsen Steel melt shop. In Proceedings of Unified International Technical Conference on Refractories, Brazil, 2009.

[21] JUNG, S. M.; FRUEHAN, R. J., Foaming Characteristics of BOF slags. ISIJ International, v. 40, n. 4, p.348-355, 2000.

[22] E.B. Pretorius and R.C. Carlisle, "Foamy Slag Fundamentals and Their Practical Application to Electric Furnace Steelmaking," Iron and Steelmaker, 1SS, 26(10), 1999, pp. 79-88. 